\title{
THE MASS BALANGE OF THE SEA ICE OF THE ARCTIC OCEAN
}

\author{
By R. M. KoeRner \\ (Polar Continental Shelf Project, Department of Energy, Mines and Resources, Ottawa, \\ Ontario, Canada)
}

\begin{abstract}
From data taken on the British Trans-Arctic Expedition it is calculated that $9 \%$ of the Arctic Ocean surface between the North Pole and Spitsbergen was hummocked or ridged ice, $17 \%$ was unridged ice less than a year old, $73 \%$ was unridged old ice and $0.6 \%$ was ice-free. The mode of 250 thickness measurements taken through level areas of old floes along the entire traverse lies between 2.25 and $2.75 \mathrm{~m}$. The mean end-of-winter thickness of the ice is calculated to be $4.6 \mathrm{~m}$ in the Pacific Gyral and $3.9 \mathrm{~m}$ in the TransPolar Drift Stream. From measurements of the percentage coverage and thickness of the various ice forms, it is calculated that the total annual ice accumulation in the Arctic Ocean is equivalent to a continuous layer of ice $1.1 \mathrm{~m}$ thick. $47 \%$ of this accumulation occurs in ice-free areas and under ice less than I year old. $20 \%$ of the total ice production is either directly or indirectly related to ridging or hummocking. An iceablation rate of $500 \mathrm{~kg} \mathrm{~m}^{-2}$ measured on a level area of a multi-year floe is compared with the rate on deformed and ponded ice. Greatest melting occurs on new hummocks and least on old smooth hummocks. The annual balance of ice older than $\mathrm{I}$ year but younger than multi-year ice is calculated from a knowledge of ice-drift patterns and the percentage coverage of first-year ice. The same calculations give a mean-maximum drift period of 5 years for ice in the Trans-Polar Drift Stream and 16 years in the Pacific Gyral. It is calculated that for the period February I 968 to May 1969 the annual ice export was $5580 \mathrm{~km}^{3}$.
\end{abstract}

RÉsumé. Le bilan de masse de la glace de mer de l'Océan Arctique. A partir de données recueillies par l'expédition trans-Arctique britannique, on a calculé que $9 \%$ de la surface de l'Océan Arctique entre le Pôle Nord et le Spitsbergen était occupé par de la glace en hummock ou ridée, $17 \%$ étant de la glace non ridée de moins d'un an, $73 \%$ de la vieille glace non ridée et $0,6 \%$ libre de la glace. Le résultat des 250 mesures d'épaisseur prises à travers les zones plates de la vieille banquise tout au long de la traversée reste compris entre 2,25 et $2,75 \mathrm{~m}$. L'épaisseur moyenne de fin d'hiver est, d'après les calculs, de 4,6 $\mathrm{m}$ dans le tourbillon Pacifique et de 3,9m dans le "Trans-Polar Drift Stream". Les mesures du taux de couverture et de l'épaisseur des différentes formes de glace permettent de calculer que l'accumulation totale annuelle de la glace est épaisse de I, I $\mathrm{m}$. $47 \%$ de cette accumulation se produit dans des zones libres de glace et sous une glace vieille de moins d'un an. $20 \%$ de la production totale de glace est directement ou indirectement liée à la formation de rides ou de hummock. Un taux d'ablation de la glace de $500 \mathrm{~kg} \mathrm{~m}^{-2}$ mesuré sur une aire plate d'une banquise pluriannuelle est comparé avec le taux sur de la glace déformée ou chargée. La fusion la plus intense est observée sur les hummocks de formation récente, la moins intense sur les hummocks vieux aux formes adoucies. Le bilan annuel de la glace de plus d'un an, mais plus jeune que les glaces multiannuelles, est calculé d'après une connaissance des mouvements de la glace et le pourcentage de couverture de la glace de première année. Les mêmes calculs donnent une moyenne de 5 ans pour la période maximum de transport par le vent dans le "Trans-Polar Drift Stream" et de 16 ans dans le tourbillon Pacifique. On a calculé que pour la période de février 1968 à mai 1969 , l'exportation annuelle de glace était de $5580 \mathrm{~km}^{3}$.

Zusammenfassung. Der Massen Bilanz des Meereises aus dem Arktischen Ozean. Aus den bei der britischen Trans-Arktis-Expedition gewonnenen Daten wurde errechnet, dass $9 \%$ der Oberfläche des Arktischen Ozeans zwischen dem Nordpol und Spitsbergen mit buckligem oder aufgewölbtem Eis, $17 \%$ mit rückenfreiem Eis von weniger als einem Jahr Alter, $73 \%$ mit rückenfreiem, altem Eis bedeckt und $0,6 \%$ eisfrei waren. Der Hauptteil der 250 Dickenmessungen an ebenen, alten Eisschollen entlang der gesamten Route ergab Dicken zwischen 2,25 m und 2,75 m. Die mittlere Eisdicke am Winterende wurde für das Pazifische Becken zu 4,6 $\mathrm{m}$ und im Transpolaren Driftstrom zu 3,9 m errechnet. Aus Messungen der prozentualen Bedeckung und Dicke der verschiedenen Eisarten ergibt sich, dass die gesamte jährliche Eisakkumulation im Arktischen Ozean einer gleichmässigen Eisschicht von $1,1 \mathrm{~m}$ Dicke entspricht. $47 \%$ dieser Akkumulation erfolgt in eisfreien Gebieten oder unter Eis von weniger als einem Jahr Alter. 20\% der gesamten Eisproduktion sind entweder direkt oder indirekt mit der Bildung von Rücken oder Buckeln verbunden. Die Ablationsrate von $500 \mathrm{~kg} \mathrm{~m}^{-2}$, die in einem ebenen Gebiet einer mehrere Jahre alten Eisscholle ermittelt wurde, wird mit der Rate für deformiertes und Wasserlachen bildendes Eis verglichen. Die stärkste Abschmelzung tritt an neuen, die geringste an alten, flachen Eisbuckeln auf. Die Jahresbilanz von Eis zwischen einem und mehreren Jahren Alter wurde aus der Kenntnis der Eisdriftsysteme und der prozentualen Bedeckung mit einjährigem Eis berechnet. Dieselben Berechnungen ergeben eine mittlere Maximaldriftperiode von 5 Jahren für Eis im Transpolaren Driftstrom und von 16 Jahren im Pazifischen Becken. Für die Periode von Februar 1968 bis Mai i 969 wurde ein jährlicher Eisausstoss von $5580 \mathrm{~km}^{3}$ errechnet.

\section{INTRODUGTION}

The Arctic Ocean ice pack constitutes the largest area of ice in the Northern Hemisphere. Consequently, the ice pack has a profound influence on global atmospheric circulation. However, very little is known about the ice cover in the Arctic Ocean-its thickness and the 
balance between the amount of ice forming in winter and the amount that either decays in summer or drifts out of the Arctic Ocean throughout the year. This lack of knowledge is partly due to the necessity of establishing research stations on thick and stable old floes. As a result, while the ice and heat balance of old floes has been well studied, the extent and balance of the other ice types has not. It is the purpose of this paper to present data on the extent, ablation and thickness of the various ice types and to use these data to calculate the total ice accumulation and ablation in, and ice export from, the Arctic Ocean.

Unless stated otherwise, ice volumes are expressed in terms of an equivalent ice thickness (in $\mathrm{m}$ ) either measured over the total ice and ice-free area (e.g. $\hat{c}$ ) or over the area covered by the type of ice denoted by the suffix (e.g. $\left.\bar{c}_{\mathrm{I}}\right)$. If, for example, the area of reference is the entire Arctic Ocean, where $c$ represents accumulation and the suffix I represents first-year ice, then $\bar{c}_{\mathrm{I}}$ is the mean thickness of first-year ice in the Arctic Ocean and $\hat{c}_{\mathrm{I}}$ is the thickness of the same volume of ice considered as a continuous layer covering the entire ocean surface. Areas (e.g. $\left.S_{\mathrm{I}}\right)$ are always expressed as percentages of the total ice and ice-free areas $\left(S_{\mathrm{t}}\right)$.

\section{Methods}

Between 2 I February I 968 and 27 May I969, the British Trans-Arctic Expedition (BTAE) crossed the Arctic Ocean between Barrow, Alaska, and a small island off the coast of Spitsbergen (Fig. I).

In order to study the regional variations of surface topography an ice log was kept during the journey. Between Barrow and the North Pole a summary of ice forms was made at the end of each day. Between the North Pole and Spitsbergen the estimated height of each ridge, the thickness of the ice slabs forming the ridge and the size and type of floes were recorded.

Over 250 holes were drilled through old and first-year ice to determine its thickness. Generally, one hole was drilled each day. $78 \%$ of the holes were drilled through old ice and the remainder through thick first-year ice. In addition, more than ioo thickness measurements

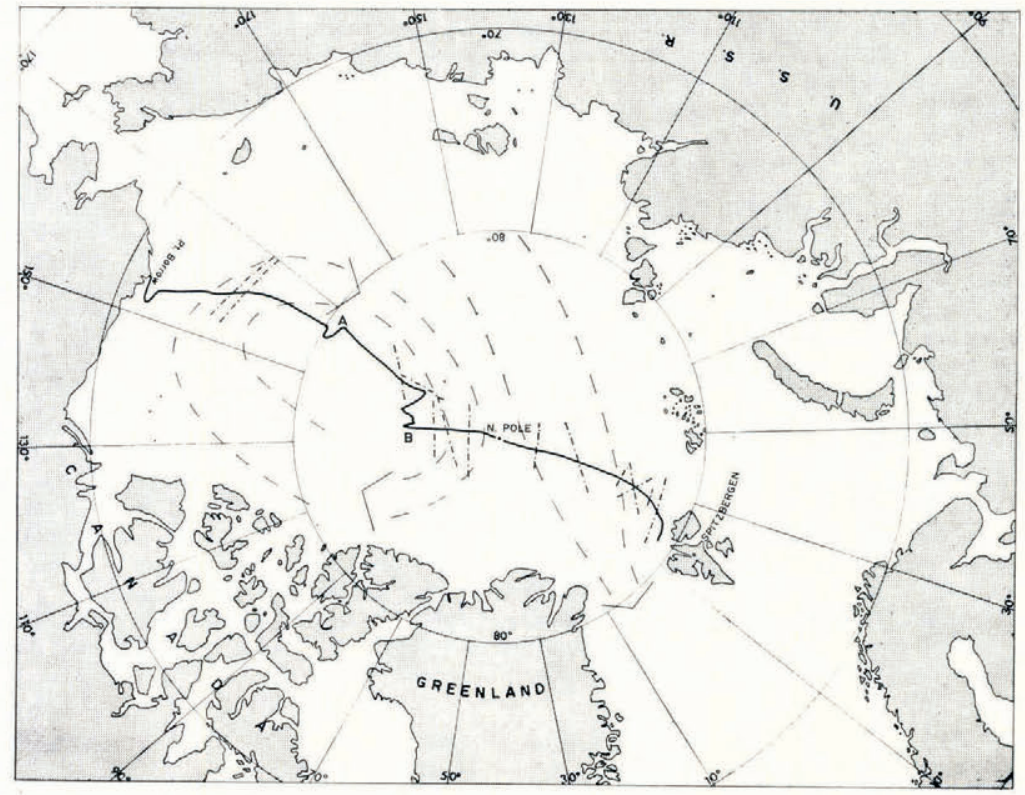

Fig. I. The Arctic Ocean showing the route of the British Trans-Arctic Expedition. The broad arrows show the two main directions of ice drift. The Pacific Gyral lies between Point Barrow and the North Pole, and the Trans-Polar Drift Stream is on the Russian side of the Pole. The BTAE drifted from A to B between July 1968 and February 1969. 
were made through ice less than $0.5 \mathrm{~m}$ thick to estimate its load capacity. From these data the ice growth and overall ice thickness in winter have been calculated.

During July and August 1968 the expedition camped on a giant floe which drifted between lat. $81.5^{\circ}$ N. and lat. $84.0^{\circ}$ N. (Fig. I). During this period, the ablation of the floe ice was studied. Ice ablation was measured at an ablatometer and two stakes, all on multi-year floes. The ablatometer consisted of two stakes frozen into the ice $2.5 \mathrm{~m}$ apart and joined by a cord. The mean height of the cord above the ice was measured daily. Bottom ice ablation was measured by repeated drilling at two sites. To relate these measurements to ablation over the entire surface, two sets of precise levelling traverses were made across $74^{2} \mathrm{~m}$ of floes. The traverses included both new and old ridges. The first set was made on 17 and 18 July and the second on 28 August.

\section{Accuracy}

As the prime motive of the expedition was not a scientific one, the majority of the observations made during the travel periods were recorded while on the move. Due to the difficulty of distinguishing between first-year and second-year ice under a snow cover, any ice of indeterminate age was recorded as "old ice". Because of this, the coverage of first-year ice has been underestimated by approximately $2 \%$.

No device was used to measure distance while travelling so that all the ice-log observations are estimates. The total mileage travelled between the North Pole and Spitsbergen has been calculated from both the ice log and the astro-fixes. The ice-log mileage is $12 \%$ less than the true mileage. Part of this error is due to the fact that the estimated distance was often omitted from the ice log during periods when no observations were recorded. The ice-drift direction between the North Pole and Spitsbergen was favourable to the expedition and this may account for up to half of the distance error. The remaining error is believed to be evenly distributed throughout the data. To minimize the distance error, the relative and not the absolute cover of each ice type has been used.

The BTAE data were recorded from a single traverse and therefore may not be representative of the entire Arctic Ocean. It is impossible at the present time to determine the typicality of the data, but it will be seen later that they are, in many respects, in reasonable agreement with theoretical considerations of both the heat balance and the pattern of ice drift in the Arctic Ocean. The relative coverage of each ice type along the traverse route is believed correct to within $\pm 5 \%$. However, the final values for total accumulation, ablation and export, because some series of measurements are incomplete and unrepresentative, may be in error by as much as $\pm 50 \%$.

\section{Results}

The ice balance $(B)$ of the Arctic Ocean can be expressed by

$$
B=C-A-G
$$

where $C$ and $A$ are the accumulation and ablation of ice, and $G$ is the amount of ice that drifts out of the Arctic Ocean. To calculate the values in Equation (I), the relative coverage as well as the thickness of each ice type at the beginning and end of the melt season need to be known.

\section{Relative coverage of deformed, old and young ice and ice-free areas (Table I; Fig. 2)}

To compare the surface observations with those taken by nuclear submarine, the extent of ridges and hummocks below the water line (i.e. keels and bummocks) has been calculated from a pressure-ridge model (paper in preparation by R. M. Koerner) similar to that of Wittmann and Schule (1966). From a study of under-ice profiles recorded by U.S. nuclear submarines, Wittmann and Schule ( 1966 ) found that $18 \%$ of the ice was ridged in the winter of I 960 and $13 \%$ in the summer of 1962 . There is a difference of $3 \%$ between the BTAE and the 
submarine data. Old bummocks and ice keels have presumably been included in the calculation from the submarine profiles whereas, in the present data, ridges and hummocks more than 2 years old and smoothed by summer ablation, were recorded as unridged old ice. The difference in definition and a genuine annual variation may account for the $3 \%$ discrepancy between the BTAE and submarine data.

TABle I. ICE TYPE, EXPRESSED AS A PERCENTAGE OF DISTANCE COVERED

Old ice

Ice $\mathrm{O}-0.3 \mathrm{~m}$ thick

Ice $0.3^{-1} .0 \mathrm{~m}$ thick

New ice $>1.0 \mathrm{~m}$ thick

Hummocked or ridged ice

Bummocks and keels

Ice-free

$$
\begin{aligned}
& \begin{array}{l}
\text { Percentage } \\
\text { Trans-Polar }
\end{array} \\
& \text { Drift ice Gyral } \\
& \begin{array}{r}
73.0 \\
\text { I. } 6
\end{array} \\
& 5 \cdot 3 \\
& \text { IO. I } \\
& 9.2 \\
& \begin{array}{c}
(14.5) \\
0.6
\end{array} \\
& \left\{\begin{array}{c}
83.0 \\
8.0 \\
10.0 \\
? \\
1.0-2.0
\end{array}\right.
\end{aligned}
$$

The Trans-Polar Drift Stream data were taken from February to May 1969 and the Pacific Gyral data from April to July 1968.
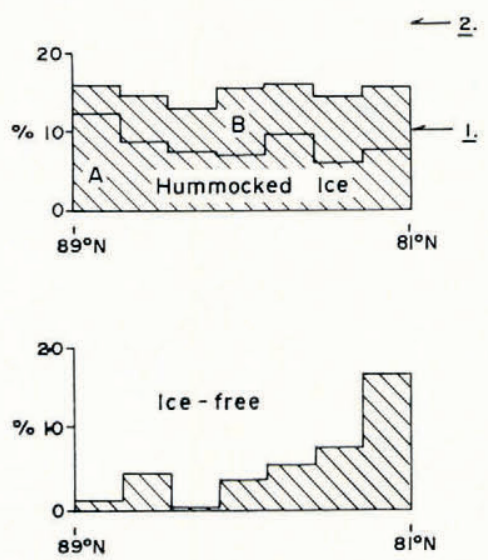
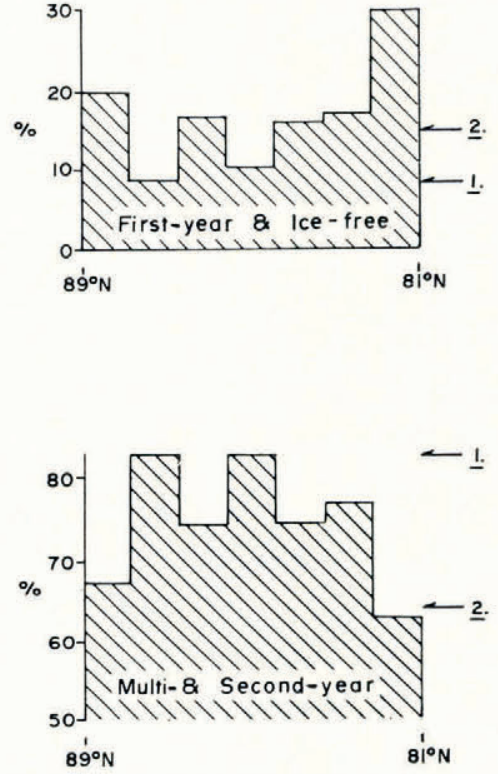

Fig. 2. Distribution of ice types between lat. $89^{\circ} \mathcal{N}$. and lat. $81^{\circ} \mathcal{N}$. along approximately long. $30^{\circ}$ E. expressed as a percentage of total area. 1. Mean value in the Pacific Gyral; 2. Mean value in the transition zone; A. Hummocks and ridges; B. Bummocks and keels.

In this paper, the term ice-free is used with reference both to areas where no sea ice is present and to areas where there is a cover of frazil ice or grease ice, as both of these ice types form in a few hours in mid-winter. Between the North Pole and Spitsbergen, only o. $6 \%$ of the area crossed by the expedition was ice-free (Table I; Fig. 2). In March and early April, when the expedition was within a few degrees of the North Pole, only $0.2 \%$ of the area was ice-free. Badgley (1966), on theoretical grounds, considered that less than $1 \%$ of the Central Arctic Ocean should be ice-free in winter; Untersteiner (1964) considered the coverage to be less than $0.5 \%$. Profiles taken by U.S.S. Sargo in the winter of 1960 found an ice-free coverage of 
I.8\% (Wittmann and Schule, I966). "Birds-eye" flight data give a mean winter ice-free coverage which is I $1.0 \%$ of the total area (Wittmann and Schule, I966); this percentage seems unreasonably high. The difference between the BTAE and submarine ice-free coverage values may in part be attributable to differences in time and place of observation. However, it is possible that the submarine-profiling system used in 1962 was unable to distinguish between an ice-free surface and very thin ice. It is interesting to note that $3.0 \%$ of the ice crossed in April ig69 was $0.3 \mathrm{~m}$ or less thick. This suggests the submarine profiler was at least capable of distinguishing between ice less than $0.3 \mathrm{~m}$ thick and ice-free areas. The high percentage of ice-free areas in the Gyral (Table I) is due to the lateness of the period of observation which extended into the summer months.

Nilas, young and first-year ice will be referred to collectively as first-year ice. The first-year ice coverage shown in Table I and Figure 2 is an underestimate by about $2 \%$ of the true value. Wittmann and Schule (1966, p. 237) calculated from "Birds-eye" flight data a $14 \%$ coverage for a similar ice type in the Trans-Polar Drift Stream. In the present data, the Gyral shows the smaller first-year ice coverage and this is in agreement with theoretical considerations of ice drift in the Arctic Ocean (e.g. Campbell, 1965), which predict a higher occurrence of convergent ice flow in the Pacific Gyral than elsewhere. The most extensive coverage of first-year ice crossed by the BTAE was between lat. $85^{\circ} \mathrm{N}$. and lat. $88^{\circ} \mathrm{N}$. along long. $140^{\circ} \mathrm{W}$. (Fig. I). This indicates that there was considerable divergent movement in that area during the I968-69 winter. The position of the area, on the edges of both the Gyral and Trans-Polar Drift Stream, may account for the scale of divergent movement. However, it is probably a transition zone that varies in position from year to year. For example, the Plaisted expedition approaching the North Pole from Ellesmere Island in April ig68, found large numbers of heavy old floes in the transition zone and at the North Pole (Aufderheide and Pitzl, I970). This suggests that in I968 the Gyral extended its influence to at least the North Pole. A year later, the BTAE saw very few Gyral floes near the North Pole and, from a change in the topography, the northern edge of the Trans-Polar Drift Stream was estimated to be situated along lat. $88^{\circ}$ N. on the Canadian-U.S.A. side of the North Pole.

\section{Ice thickness (Fig. 3; Tables I and II)}

Despite the fact that $75 \%$ of the thickness measurements were taken through old ice, there is a wide range of thicknesses (Fig. 3). Even when the first-year ice and hummock sites are excluded from the data, there is still no well-defined mode which can be identified as a steady-state thickness. The thickness of unhummocked ice can vary by more than $1.5 \mathrm{~m}$ on the same multi-year floe even though the floe may be several years old. A single steady-state thickness, therefore, seems to be theoretical. Instead, there is probably a separate steady-state thickness for each basic old-ice type. A mean multi-year floe thickness is more important for the purposes of the present study. This may be termed a mean steady-state thickness $\bar{h}_{\mathrm{ss}}$ which is dependent on the relative coverage and thickness of hummocked, ponded and level, unponded ice. The relative coverages have been measured from a set of air photographs taken by the Polar Continental Shelf Project in the Lincoln Sea in July 1968, and from photographs taken by the BTAE. The mean thickness of undeformed old ice is taken from the ice-thickness data. A mean hummock thickness of $\mathrm{I} 3 \mathrm{~m}$ has been estimated from a levelling profile across a multi-year floe and an above/below relationship of 1 : 7. (Density of old sea ice $=0.7 \mathrm{Mg} \mathrm{m}^{-3}$ (Weeks and Lee, I958) and sea-water density $=1.025 \mathrm{Mg} \mathrm{m}^{-3}$ (Cabaniss, I962), $\bar{h}_{\mathrm{ss}}$ is calculated to be $3.5 \mathrm{~m}$ in the Pacific Gyral, 3.0 $\mathrm{m}$ in the Trans-Polar Drift Stream and $3.2 \mathrm{~m}$ in the transition zone between the two. The BTAE measurements showed no significant difference between the thickness of undeformed ice in the Pacific Gyral and the Trans-Polar Drift Stream so that the high $\bar{h}_{\mathrm{ss}}$ value in the Pacific Gyral must be due to the larger number of hummocks on the relatively old multi-year floes there. 


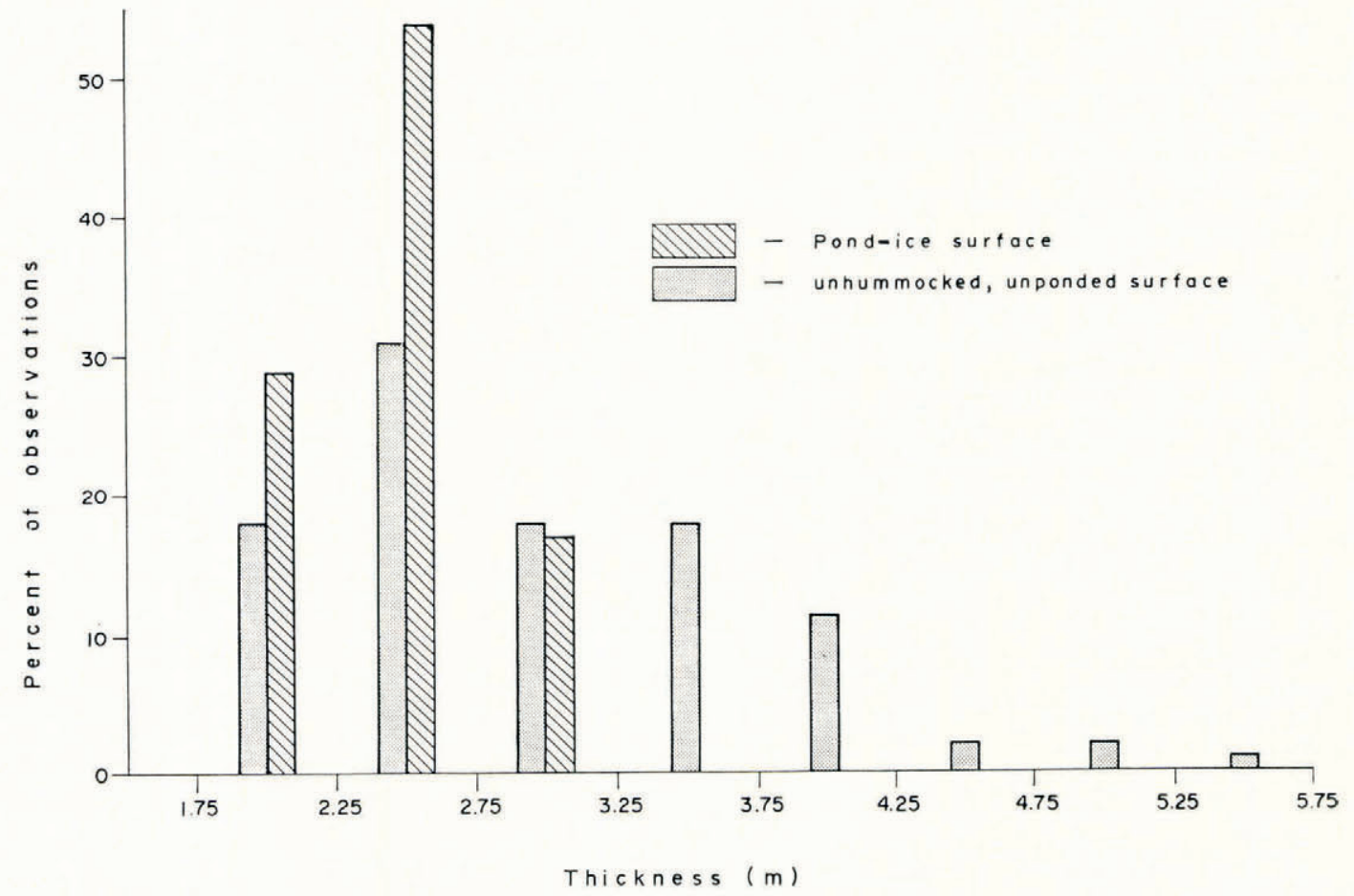

Fig. 3. Ice thickness (\%) of floes more than $1.5 \mathrm{~m}$ and less than $4.5 \mathrm{~m}$ thick.

Table II. Annual ice export $(g)$, accumulation $(c)$, ablation $(a)$, balance $(b)$ AND THickness $(h)$ IN THE Arctic Ocean (m OF ICE)

\begin{tabular}{lcccccccc}
\multicolumn{1}{c}{ Region } & $\hat{g}_{\mathrm{t}}$ & $\hat{a}_{\mathrm{t}}$ & $\hat{c}_{\mathrm{I}}$ & $\hat{b}_{\mathrm{I}}$ & $\hat{b}_{\mathrm{n}}$ & $\hat{b}_{\mathrm{ss}}$ & $\hat{h}_{\mathrm{t}(\mathrm{p})}$ & $\hat{h}_{\mathrm{t}(\mathrm{e})}$ \\
Trans-Polar Drift Stream & 0.6 & 0.6 & 0.6 & 0.5 & 0.2 & 0 & 3.9 & 3.7 \\
Pacific Gyral & 0.5 & 0.6 & 0.4 & 0.3 & $0 . \mathrm{I}$ & $\mathrm{o}$ & 4.6 & $4 \cdot 3$ \\
Transition zone & 0.3 & 0.7 & 0.4 & 0.2 & $0 . \mathrm{I}$ & 0 & 4.4 & $4 \cdot \mathrm{I}$
\end{tabular}

All values are the equivalent of a continuous ice layer covering the region referred to in the first column. $\mathrm{t}$ is a total value; $\mathrm{I}$ - first-year ice, ss-floes of steady-state thickness; $n$-floes older than first-year but younger than steady-state floes, $(p)$ perimeter thickness at the end of winter (see text), (e)-effective thickness at the end of winter (see text).

First-year ice covers a wide range of thicknesses (Table I). New ice beginning its growth in September can be identified by the fresh-water ice at its surface; seven measurements through this ice in late May gave a mean thickness of $2.04 \mathrm{~m}$, which may be considered a season's maximum growth from open water.

The mean thickness of the entire ice cover crossed by the expedition, $\hat{h}_{\mathrm{t}}$, has been calculated from the extent and thickness of each ice type, including both undeformed and deformed ice. The three values for $\bar{h}_{\mathrm{ss}}$ already calculated have been used in the computation of $\hat{h}_{\mathrm{t}}$. The estimated or measured thickness of each area of undeformed first-year ice and the calculated thickness of deformed ice (based on the height of the feature above the water line) have been entered into the calculations separately. Two mean values are calculated. The first value $\hat{h}_{\mathrm{t}(\mathrm{p})}$ considers the cavities formed during the process of deformation as ice. The second value $\hat{h}_{t(\mathrm{e})}$ is an equivalent ice thickness from which the cavities have been excluded. The latter is the more important of the two values in any consideration of the ice balance. 
The results are shown in Table II. $\hat{h}_{\mathrm{t}}$ is greatest in the Pacific Gyral, again because of the larger number of old hummocks, but also due to the more massive nature of the ridges there; this is in accord with both the theoretical and observed patterns of ice drift in the Arctic Ocean.

\section{Ice and snow accumulation (c) (Tables II, III and IV)}

In this context, ice accumulation is the volume of ice forming in the Arctic Ocean in any one balance year. Although ice growth was measured at several sites on both new and old ice, the measurements do not cover a complete growth period. The results are shown in Table III and the high growth rate of first-year ice underlines the importance of fracturing in the process of ice accumulation.

Table III. Ice growth $\left(\mathrm{mm} \mathrm{d}^{-1}\right)$ in the central Arctic Ocean, September 1968 to February ig69

$\begin{array}{lcccccc} & \text { Sept. } & \text { Oct. } & \text { Nov. } & \text { Dec. } & \text { Jan. } & \text { Feb. } \\ \text { From open water; first 5 d } & 20-40 & 40 & - & - & 50-70 & 60 \\ \text { From open water; first 30 d } & 18 & 19 & 2 \text { I } & - & 28 & 25 \\ \text { Under I m thick ice } & - & - & - & - & 10-20 & - \\ \text { Under 2-3 m thick old ice } & \text { o to }-2 & \text { o } & 0 & 0-2 & 0-4 & -\end{array}$

A negative figure denotes ablation, and a bar denotes no observation.

First-year ice may be in either unridged or ridged forms. In the process of ridging of new ice, some old ice is often incorporated in the ridge. Between the North Pole and Spitsbergen, $16 \%$ of the new ridges contained some old ice. However, the total amount of old ice in firstyear ridges is probably no more than $5 \%$ and the calculations of the amount of new ice in ridged form have been corrected by this amount.

The amount of new and first-year ice crossed by the expedition (i.e. the winter balance of ice less than I year old) is given in Table II. Errors are due to:

i. An incorrect assessment of ice thickness.

ii. Misidentification of some second-year ridges for first-year ridges.

iii. Misidentification of first-year ice for old ice.

The errors under (i) are probably self-cancelling, and the errors under (iii) are believed to exceed those under (ii). The calculations therefore underestimate the amount of first-year ice.

Between 5 October 1968 and 23 February 1969 , ice accumulation in fractures forming in an area approximately $5 \mathrm{~km}$ square was measured daily. The thickness of ice forming in new fractures was measured by drilling. The estimates of fracture width have an error of about $5 \%$ when made in periods of moonlight, but about $20 \%$ in periods of darkness when a battery spotlight was used. The total ice accumulation in fractures in the study area is shown in Table IV. Between 5 October I968 and 2 January I969, the figures refer essentially to three $400 \mathrm{~m}$ by $600 \mathrm{~m}$ floes and the fractures at their edges. After 2 January 1969 , the study area included two large polynyas which opened at the edges of the floes. The polynyas increased the new-ice coverage in the study area to $70 \%$ which is clearly unrepresentative of the Pacific Gyral as a whole. If the growth rate of ice in fractures between 5 October I 968 and 2 January I969 is extrapolated to cover a I September to mid-May growth period, the annual

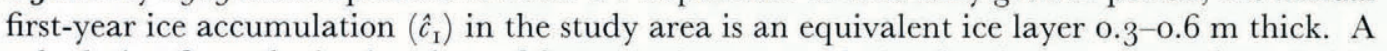
calculation from the ice-log data of first-year ice accumulation for the same growth period in the Pacific Gyral gives a comparable layer $0.5 \mathrm{~m}$ thick. 
Table IV. Ice growth in a small area in the central Arctic Ocean, 5 October ig68 to 22 February 1969. (mm OF ICE A DAY, EXPRESSED AS A CONTINUOUS LAYER COVERING THE ENTIRE AREA EXAMINED (i.e. $\hat{c}$ )

Total new ice growth 5-20 Oct. 20 Oct.-14 Dec. $\quad{ }_{14}$ Dec.-2 Jan. $\quad 2$ Jan.-22 Feb.

New ice growth in recurring fracture 3

New ice growth in polynyas

New ice growth elsewhere

Old ice growth

$\begin{array}{cc}3 & 2 \\ \mathrm{I}-2 & \mathrm{I}-2 \\ 0 & 0 \\ \mathrm{I}-2 & 0-\mathrm{I} \\ 0 & 0\end{array}$

16
2
13
I
4

Ice growth under steady-state floes is well documented in the literature where values vary between 0.4 and $0.5 \mathrm{~m}$ of ice per year. However, the annual ice accumulation under old ice must be higher than this as it includes ice older than I year but of less than steady-state thickness. So that with a first-year annual ice accumulation $\left(\hat{c}_{\mathrm{I}}\right)$ of about $0.5 \mathrm{~m}$ of ice and an old-ice annual accumulation slightly greater than $0.4^{-0.5} \mathrm{~m}$ of ice, the contributions to the positive side of the ice balance of the two basic ice types are quite similar.

Snow accumulation was measured on the BTAE by probing to the ice surface in ten different places and taking one set of density measurements at each of $3^{8}$ locations. The measurements were taken in the middle of large floes. The results are shown in Figure 4 . Because snow is blown into open fractures and into hummock fields, the snow accumulation on the floes is less than the total precipation. There is a significant increase (at the $<\mathrm{r} \%$ level) of snow accumulation towards each end of the traverse. The pattern is probably related to greater cyclonic activity round the periphery of the Arctic Ocean (Wilson, 1963, p. 268-69).

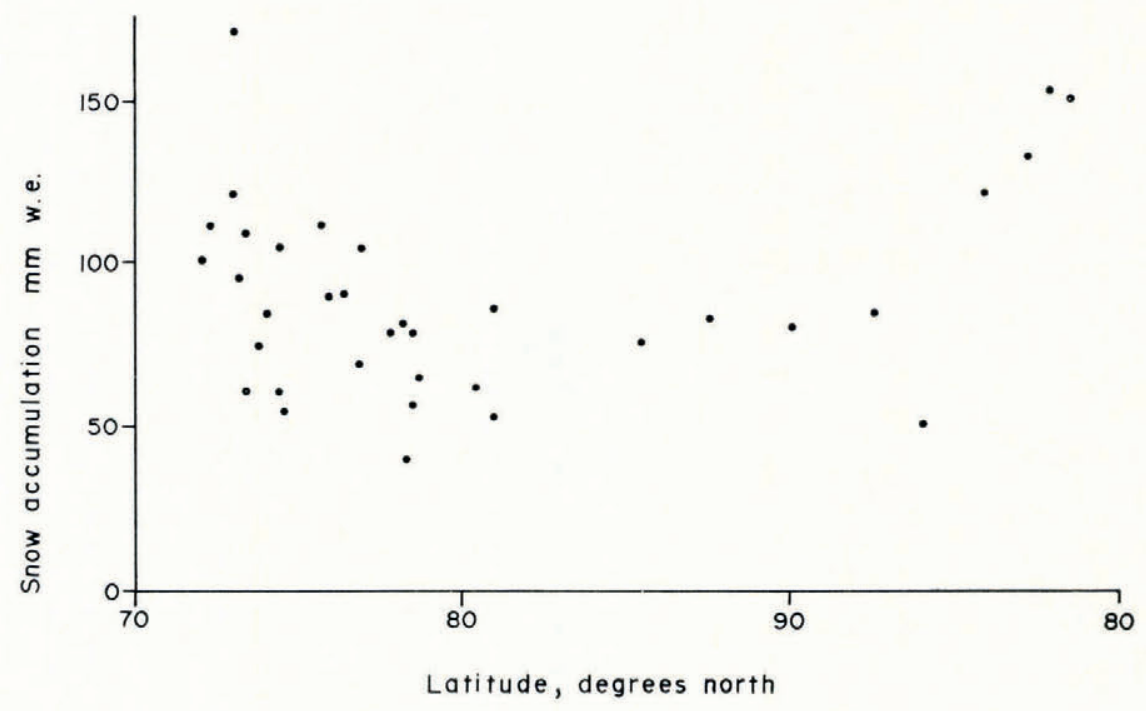

Fig. 4. Snow accumulation between Point Barrow (lat. $71^{\circ} \mathcal{N}$.) and Spitsbergen (lat. $81^{\circ} \mathcal{N}$.).

Superimposed ice forms in June at the base of the snowpack, particularly in depressions on the floes; 20-30 $\mathrm{mm}$ of this ice formed in June 1968 .

Fresh-water ice forms at the interface between salt and fresh water in summer. In I968, $20 \mathrm{~mm}$ of this ice formed in fractures at a depth of $1.5 \mathrm{~m}$, equivalent to a continuous layer 2-4 mm thick. 


\section{Ablation (Table II)}

The measured ablation of a multi-year floe in 1968 was $500 \mathrm{~kg} \mathrm{~m}^{-2}$ (i.e. a layer of ice $0.55 \mathrm{~m}$ thick). Precise levelling transects over the floe surface at the beginning and end of the melt season showed that the ablation of the surface ice is non-uniform (Table V). These observations indicated that hummocks, with an albedo about $10 \%$ higher than that of level ice (Koerner, I970), are self-perpetuating. The total ablation at the level site has been weighted according to the data in Table $\mathrm{V}$ to give a mean ablation $\bar{a}_{\mathrm{ss}}$ of $0.5 \mathrm{~m}$ of ice.

\begin{tabular}{|c|c|}
\hline & Percentage \\
\hline $\begin{array}{l}\text { New ridge } \\
\text { Old hummocks }\end{array}$ & $\begin{array}{r}260 \\
6 \mathrm{r}\end{array}$ \\
\hline Level areas & 100 \\
\hline Ponds, ice surface & 168 \\
\hline Ponds, water surface & 73 \\
\hline
\end{tabular}

Because fracturing made first-year ablation sites inaccessible, a continuous record of the ablation of first-year ice, $\bar{a}_{1}$, was not taken. However, Yanes (r962), from measurements taken at U.S.S.R. floe stations, formulated the empirical relationship

$$
\bar{a}_{\mathrm{I}}=\mathrm{I} .4 \bar{a}_{\mathrm{ss}} \text {. }
$$

Although Yanes (I962) did not specify what type of multi-year ice surface $\bar{a}_{\mathrm{ss}}$ refers to, it is assumed to represent the ablation of level ice $\bar{a}_{\mathrm{ss}(\mathrm{d})} ; \bar{a}_{\mathrm{I}}$ is then equal to an ice layer $0.8 \mathrm{~m}$ thick.

The ablation of new ridges $\bar{a}_{\mathrm{r}}$ and hummocks, $\bar{a}_{\mathrm{h}}$ is 2.6 times as great as that of undeformed multi-year ice $\bar{a}_{\mathrm{ss}(\mathrm{d})}\left(\right.$ Table V). However, a ridge or hummock field contains about $\mathrm{I}_{5} \%$ cavities so that ablation there is:

$$
\bar{a}_{\mathrm{r}}=\bar{a}_{\mathrm{h}}=0.85\left(2.6 \bar{a}_{\mathrm{ss}(\mathrm{d})}\right)=\mathrm{I} .2 \mathrm{~m} \text {. }
$$

Both the snow cover and superimposed ice layer ablated completely in the summer of I968 in the vicinity of the camp (Fig. I). The interface ice layer did not appear to ablate at all but was incorporated into the winter ice layers.

\section{Balance (Table II)}

The mass balance of first-year ice is positive (i.e. $\bar{c}_{\mathrm{I}}>\bar{a}_{\mathrm{I}}$ ), whereas the balance of steadystate floes is zero $\left(\bar{c}_{\mathrm{ss}}=\bar{a}_{\mathrm{ss}}\right)$. However, the mass balance of old ice of less than steady-state thickness must be positive; as no separate study of floes of this age was made, the ice balance on them must be calculated.

To attain a mean steady-state thickness $\bar{h}_{\mathrm{ss}}$, a first-year floe of thickness $\bar{h}_{1}$ must have a total net balance, $\bar{b}_{n(\mathrm{t})}$, of $\bar{h}_{\mathrm{ss}}-\bar{h}_{\mathrm{I}}$ over a period $m-\mathrm{I}$ years, where $m$ is the age in years of a floe which has just attained steady-state thickness. The value for a full season's growth quoted previously $(2.04 \mathrm{~m})$ can be used for $\bar{h}_{\mathrm{I}}$ as ice thicker than this is in second year of growth. Using the previously calculated values of $\bar{h}_{\mathrm{ss}}$ in $\bar{h}_{\mathrm{ss}}-\bar{h}_{\mathrm{I}}$, the value of $\bar{b}_{n(\mathrm{t})}$ where I $<n<m$ years is $1.42 \mathrm{~m}$ in the Pacific Gyral, I. $19 \mathrm{~m}$ in the transition zone and $0.96 \mathrm{~m}$ in the Trans-Polar Drift Stream.

Ice drift in the Trans-Polar Drift Stream may be considered as stream flow where ice leaves the stream between Greenland and Spitsbergen. As a first approximation, therefore:

$$
S_{1} \approx S_{2} \approx S_{3}=\ldots S_{T}
$$


where $S$ is the area of ice $1,2,3$, and $T$ years old. $T$ is the age, in years, of the oldest ice commonly present and is given by:

$$
T=S_{\mathrm{t}} \tau / S_{\mathrm{I}}
$$

where $\tau \equiv$ I year. In this case, $S_{\mathrm{I}}$ includes areas of ridged and hummocked new and first-year ice. In the Trans-Polar Drift Stream $S_{\mathrm{I}}$ is equal to $19.9 \%$ of $S_{\mathrm{t}}$ so that $T$ is 5 years. However, hummocking annually reduces the area of old ice by an amount $R$ which can be calculated from

$$
R=\frac{\tau}{T}\left(\frac{S_{\mathrm{q}} \bar{h}_{\mathrm{q}}}{\bar{h}_{\mathrm{d}}}-S_{\mathrm{q}}\right)
$$

where $S_{\mathrm{q}}$ is the area of hummock fields composed of old ice $(6 \%$ of the total area in the TransPolar Drift Stream), $\bar{h}_{\mathrm{q}}$ is the mean hummock field thickness (ro m, a figure based on a mean above-waterline height calculated from the BTAE ice log and an above : below relationship of $\mathrm{I}: 7$ ) and $\bar{h}_{\mathrm{d}}$ is the thickness (in $\mathrm{m}$ ) of the ice before hummocking (2.5 $\mathrm{m}$ from Figure 3 ). $\left(S_{\mathrm{q}} \bar{h}_{\mathrm{q}}\right) / \bar{h}_{\mathrm{d}}$ in Equation (6) gives the original extent of undeformed ice that the hummock fields formed from; $\tau / T$ reduces the term to an annual value. In the Trans-Polar Drift Stream, $R$ is equal to $3.6 \%$ of the total ice and ice-free area. The area of ice $n$ years old $\left(S_{n}\right)$ for $n \geqslant$ I year is then given by:

$$
S_{n}=S_{\mathrm{I}}(\mathrm{I}-\phi)^{n-\mathrm{I}}
$$

where $\phi$ is $R / S_{\mathrm{t}}$.

$T$ can then be found from

$$
\left(S_{\mathrm{t}}-S_{\mathrm{I}}\right)=\int_{\mathrm{I}}^{T} S_{\mathrm{I}}(\mathrm{I}-\phi)^{n-\mathrm{I}} \mathrm{d} n .
$$

Taking a representative area of $100 \mathrm{~km}^{2}$ where $S_{\mathrm{t}}=\mathrm{I}$ I0о $\mathrm{km}^{2}, R=3.5 \mathrm{~km}^{2}$ and $S_{\mathrm{I}}=\mathrm{I} 9.9$ $\mathrm{km}^{2}, T$ is still 5 years. 5 years is in fact similar to the drift period of several Russian floe stations in the Trans-Polar Drift Stream and to the combined drift period of Maud and Fram (Dunbar and Wittmann, I963).

As, from thermodynamic considerations, there is no ice growth where $\bar{h} \geqslant \bar{h}_{\mathrm{ss}}$, the area of hummock fields more than I year old must be subtracted from the total area of old ice so that

$$
S_{n(\mathrm{~d})}+S_{\mathrm{ss}(\mathrm{d})}=S_{\mathrm{t}}-S_{\mathrm{I}}-S_{\mathrm{q}}
$$

where $S_{n(\mathrm{~d})}$ is the area of undeformed old ice of less than steady-state thickness and $S_{\mathrm{ss}(\mathrm{d})}$ is the area of undeformed ice of steady-state thickness. Untersteiner ( 1964$)$ has calculated that $\bar{h}_{\mathrm{ss}}$ is attained in 7-8 years from ice-free conditions. However, there is no significant difference between the set of old-ice thickness measurements from the Pacific Gyral and the set from the Trans-Polar Drift Stream despite the fact that ice may circulate for considerably longer periods in the Pacific Gyral. Similar old-ice thicknesses in each area, therefore, indicate that $\bar{h}_{\mathrm{ss}}$ is attained in both, i.e. in less than 5 years. In Equation (10) it is assumed that $\bar{h}_{\mathrm{ss}}$ is attained in 5 years so that $S_{\mathrm{ss}(\mathrm{d})}=0$; this assumption introduces a maximum error of $10 \%$ (i.e. $\bar{h}_{\mathrm{ss}}$ is attained in 2 years). The annual balance, $\bar{b}_{n}$, of old ice of less than steady-state thickness (i.e. where $\mathrm{I} \leqslant n \leqslant 5$ years) is given by:

$$
b_{n}=S_{n(\mathrm{~d})} b_{n(\mathrm{t})} / \frac{m-\mathrm{I}}{\tau}
$$

where $m$ is the age in years of a floe which has just attained steady-state thickness. Again, taking a representative $100 \mathrm{~km}^{2}$ area where $S_{n(\mathrm{~d})}=74 . \mathrm{Im} \mathrm{km}^{2}$ and $\bar{b}_{n(\mathrm{t})}=0.96 \mathrm{~m}, \bar{b}_{n}$ is $17.8 \mathrm{~m}^{3}$ of ice. This may be represented as a layer of ice $0.2 \mathrm{~m}$ thick spread uniformly over the I $00 \mathrm{~km}^{2}$ area (i.e. $\hat{b}_{n}$ ). 
The same arguments do not apply to the Pacific Gyral, where, due to the circulatory pattern of the drift (Fig. I), ice of all ages may drift out of the Gyral in any one year. If there is a constant decrease in the area of any one year's ice with time $R^{\prime}$ (due to both ice export and ice deformation), then

$$
S_{\mathrm{t}}=S_{\mathrm{I}}+\left(S_{\mathrm{I}}-R^{\prime}\right)+\left(S_{\mathrm{I}}-2 R^{\prime}\right)+\ldots S_{\mathrm{I}}-\left(\frac{T}{\tau}-\mathrm{I}\right) R^{\prime}
$$

as $\left(\frac{T}{\tau}-\mathrm{I}\right) R^{\prime}=S_{\mathrm{I}}-R_{\mathrm{I}}$ this reduces to

$$
T=\left[\left(2 S_{\mathrm{t}} / S_{\mathrm{I}}\right)-\mathrm{I}\right] \tau .
$$

In $1968, \mathrm{I} .5 \%$ of the ice crossed in the Gyral was in its first year. Substituting this value in Equation (12) gives $T$ equal to 16 years. As there is an exponential rather than a linear decrease in area of any one year's ice with time, I6 years must be regarded as a lower limit of $T$. There is insufficient ice-drift evidence from the Gyral at present with which to compare the calculated $T$ value. Gyral floes have never been tracked from initial growth to export. However, it is known that Fletcher's Ice Island (T-3) has drifted in the Pacific Gyral for over 20 years. Assuming again that $\bar{h}_{\mathrm{ss}}$ is attained in 5 years, the area of undeformed old ice $n$ years old $\left(s_{n(\mathrm{~d})}\right)$ where $\mathrm{I} \gtrless n \gtrless 5$ years is given by:

$$
S_{n(\mathrm{~d})}=\int_{\mathrm{I}}^{5}\left[S_{\mathrm{I}}-\left(\frac{n}{\tau}-\mathrm{I}\right) R^{\prime}\right] \mathrm{d} n
$$

where $R^{\prime}$ is $S_{\mathrm{I}} \tau / T$. Taking a $\mathrm{I00} \mathrm{km}^{2}$ representative area in the Pacific Gyral where $S_{\mathrm{I}}=\mathrm{I}$ I.5 $\mathrm{km}^{2}$ and $T=\mathrm{I} 6$ years, $S_{n(\mathrm{~d})}=40.4 \mathrm{~km}^{2}$. Then, putting $S_{n}=40.4 \mathrm{~km}^{2}$ and $\bar{b}_{n(\mathrm{t})}=\mathrm{I} .42 \mathrm{~m}$ into Equation (10) we get $\bar{b}_{n}=14.3 \mathrm{~km}^{3}$ or $\hat{b}_{n}=0.14 \mathrm{~m}$ of ice in the Pacific Gyral.

Using similar arguments in the transition zone, $\hat{b}_{n}$ there is $0.05 \mathrm{~m}$ of ice.

\section{Ice export (Table II)}

If the ice balance in the Arctic Ocean is assumed to be in a steady-state condition, then ice export is equal to the sum of the balances of first-year ice and old ice of less than steady-state thickness. The calculated regional ice export values are shown in Table II. It should be noted that $R^{\prime}$ in Equations (II) and (I3) includes both the area of ice exported and the area reduced by the effect of ice deformation. However, even assuming the value $R^{\prime}$ consists entirely of ice exported from the Pacific Gyral and the transition zone, the appropriate values for $\hat{g}_{\mathrm{t}}$ are not changed significantly.

The area of the Pacific Gyral, the Trans-Polar Drift Stream and the transition zone between has been estimated from the pattern of ice drift shown in Dunbar and Wittmann (1963, p. 92). The three regions cover $4 \mathrm{I}, 55$ and $4 \%$ of the Arctic Ocean, respectively (about $\mathrm{IO}^{7} \mathrm{~km}^{2}$ ). If the ice-export values in Table II are representative, the total annual ice export from the Arctic Ocean is $55^{80} \mathrm{~km}^{3}$, which is equivalent to a layer of ice $0.6 \mathrm{~m}$ thick spread over the entire Arctic Ocean. This means approximately $15 \%$ of the ice cover is exported each year. Gordiyenko and Karelin* estimated that an area of $\mathrm{I} 036000 \mathrm{~km}^{2}$ of ice left the Arctic Ocean each year between I933 and I944. The mean annual thickness of the entire pack ice lies somewhere between the effective thickness $\left(h_{\mathrm{t}(\mathrm{e})}\right)$ at the end of winter (Table II)) and the effective thickness at the end of the melt season in August or September (i.e. $\left.h_{\mathrm{t}(\mathrm{e})}-a_{\mathrm{t}}\right)$. Using the values shown in Table II, we obtain a mean ice thickness of $3.7 \mathrm{~m}$, which means Gordiyenko and Karelin's ice-export value is equivalent to a continuous ice layer $0.4 \mathrm{~m}$ thick

* Statement by P. A. Gordiyenko and D. B. Karelin (in Problemy Arktiki, 1945, No. 3. (Only the translation of this was available to the author.) 
$\left(3800 \mathrm{~km}^{3}\right.$ ). Vowinckel ( 1964$)$, from a study of wind and current drift into the Greenland Sea, calculated a similar value to that of Gordiyenko and Karelin. Because the BTAE data may not be representative of the whole Arctic Ocean, the value for ice export may be in error by as much as $\pm 50 \%$. However, it is believed that the data underestimate the first-year ice area in the Arctic Ocean and this leads to an underestimation of the ice export. In this case, it seems that even considering the errors in each of the three sets of calculations, the annual ice export for the period of the BTAE observations, i.e. I $967-69$, exceeded that for the periods studied by Gordiyenko and Karelin, and Vowinckel (1964). This is in agreement with the records, showing an increasing severity of ice conditions off the north coast of Iceland in the i 960 's (Kristjannsson, i 969).

\section{Conclusions}

The BTAE data, if they are representative, show that the equivalent of a continuous layer of ice I. I m thick may form in the Arctic Ocean in a year $\left(\hat{c}_{\mathrm{I}}+\hat{c}_{n}+\hat{c}_{\mathrm{ss}}\right.$, or $\left.\hat{g}_{\mathrm{t}}+\hat{a}_{\mathrm{t}}\right) .47 \%$ of this ice forms in ice-free areas and under first-year ice $\left(\hat{c}_{1}\right)$ giving a mean thickness for first-year ice, $\bar{h}_{1}$, of $3.5 \mathrm{~m}$. As no more than about $2.0 \mathrm{~m}$ of ice forms from ice-free water in a single winter, the remainder, i.e. I. $5 \mathrm{~m}$, is formed when new ice is piled into ridges and hummocks; new icefree areas then open for ice to form at a very high growth rate. Thus, about $20 \%$ of the ice production is indirectly due to ridging and hummocking. It seems likely, therefore, that variations in the amount of ice production each year in the Arctic Ocean are more dependent on variations in the amount of ridging and hummocking than on variations in the winter temperature. Consequently, comparisons between the ice-thickness measurements taken in different years are not meaningful in terms of varying ice production and climatic change unless the measurements are representative of the entire range of ice types.

\section{AcKnowledgements}

The author was supported by the Leverhulme Research Foundation while a member of the expedition. The data were analysed at the Polar Continental Shelf Project, Department of Energy, Mines and Resources, Canada. Support for the expedition came from a wide variety of sources, the foremost being the Canadian Armed Forces and the U.S. Naval Arctic Research Laboratories in Barrow, Alaska. Discussions with Drs W. S. B. Paterson and G. Holdsworth, and Mrs M. Dunbar, are gratefully acknowledged as too are the comments of an anonymous referee. The author would also like to thank the expedition leader, W. W. Herbert, without whose vision and encouragement this work could not have been undertaken.

MS. received 12 October 1971 and in revised form 12 November 1972

\section{REFERENCES}

Aufderheide, A. C., and Pitzl, G. 1970. Observations on ice regions of the Arctic Ocean. Arctic, Vol. 23, No. 2, p. $133-36$.

Badgley, F. I. 1966. Heat budget at the surface of the Arctic Ocean. (In Fletcher, J. O., ed. Proceedings of the symposium on the Arctic heat budget and atmospheric circulation, January 31 through February 4, 1966, Lake Arrowhead, California. Santa Monica, Calif., Rand Corporation, p. 267-77. (Memorandum RM-5233-NSF.))

Cabaniss, G. H., ed. 1962. Geophysical data from U.S. Arctic Ocean drift stations, 1957-1960. L. G. Hanscom Field, Mass., U.S. Air Force Cambridge Research Laboratories, Office of Aerospace Research. (AFCRL-62-683. Project 7628.$)$

Campbell, W. J. 1965. The wind-driven circulation of ice and water in a polar ocean. Fournal of Geophysical Research, Vol. 70, No. I4, p. 3279-301.

Dunbar, Moira, and Wittmann, W. I. 1963. Some features of ice movement in the Arctic Basin. (In Proceedings of the Arctic Basin Symposium, October 1962, held at Hershey, Pa., under the auspices of the Arctic Institute of North America and the Office of Naval Research, U.S. Navy. Centreville, Md., Tidewater Publishing Corp., p. 90-Io8.) 
Koerner, R. M. 1970. Weather and ice observations of the British Trans-Arctic Expedition, 1968-1969. Weather, Vol. 25, No. 5, p. 218-28.

Kristjannsson, L. I969. The ice drifts back to Iceland. New Scientist, Vol. 4I, No. 639, p. 508-og.

Untersteiner, N. 1964. Calculations of temperature regime and heat budget of sea ice in the central Arctic. Fournal of Geophysical Research, Vol. 69, No. 22, p. 4755-66.

Vowinckel, E. 1964. Ice transport in the East Greenland current and its causes. Arctic, Vol. 17, No. 2, p. I I 1-19.

Weeks, W. F., and Lee, O. S. $195^{8}$. Observations on the physical properties of sea ice at Hopedale, Labrador. Arctic, Vol. I I, No. 3, p. 134-55.

Wilson, H. 1963. The atmosphere and above. (In Proceedings of the Arctic Basin Symposium, October 1962, held at Hershey, Pa., under the auspices of the Arctic Institute of North America and the Office of Naval Research, U.S. Navy. Centreville, Md., Tidewater Publishing Corp., p. $256-70$.)

Wittmann, W. I., and Schule, J. J., jr. 1966 . Comments on the mass budget of Arctic pack ice. (In Fletcher, J. O., ed. Proceedings of the symposium on the Arctic heat budget and atmospheric circulation, January 3 I through February 4 , 1966, Lake Arrowhead, California. Santa Monica, Calif., Rand Corporation, p. 215-46. (Memorandum RM-5233-NSF.))

Yanes, A. V. 1962. Tayaniye snega i l'da v tsentral'noy Arktike [Melting of snow and ice in the central Arctic]. Problemy Arktiki i Antarktiki, Vyp. I I, p. 59-64. [Only the English translation of this was available to the author.] 